\title{
News vs Sentiments: Impact of Monetary Policy Announcement on Developed and Developing Countries' Market Performance
}

\author{
Jazib Ahmed Ansari ${ }^{1}$ \\ Research Scholar \\ Karachi University Business School, University of Karachi, Pakistan \\ Dr. Danish Ahmed Siddiqui \\ Associate Professor \\ Karachi University Business School, University of Karachi, Pakistan
}

\begin{abstract}
This paper investigates the impact of monetary policy announcements on the performance of the stock market in twenty countries (10 Developed and 10 developing). Exchange rate changes and changes in bond yield were taken as control. Daily basis Panel data was used with daily frequency for five (5) years (2014 - 2018). An impact of these selected independent variables on the stock market index is estimated using the regression model and Panel Least Square model. Monetary policy data has been run in three different lags i.e. lag (0), lag $(-1,-2,-3,-4)$, and lag $(1,2,3,4)$ in order to check the availability of monetary policy impact in pre and post announcement dates also, while the other variables run on a single lag. It is observed that the stock market of developed countries has a significant relation with monetary policy announcements, however, these announcements showed an insignificance relation with the stock market index in the case of developing countries. Moreover, exchange rates seem to have a significant effect on markets of both developing and developed countries, whereas bond yield seems to have a significant effect on the stock market of Developing countries only
\end{abstract}

Keywords: monetary policy announcements, stock market index, exchange rates, bond yields, cross country, news, sentiments

DOI: $10.7176 / \mathrm{JESD} / 11-7-05$

Publication date: April $30^{\text {th }} 2020$

\section{Introduction: -}

\subsection{Background of the Study}

Stock market prices go up and down every minute due to supply and demand fluctuations. If more and more people want to buy particular stocks, the market price will rise. Conversely, if more and more people want to sell stocks, the price will fall. This relationship between supply and demand is linked to news that is released at a particular moment. Negative news will usually cause people to sell stocks. Unexpected events, along with poor earnings reports, corporate governance, economic and political uncertainty, will translate into sales pressure and stock price decline. Positive news will usually cause people to buy stocks. Good earnings reports, increased corporate governance, new products and acquisitions, as well as positive overall economic, and political indicators, translate into buying pressure and an increase in stock price. The impact of new information on a stock depends on how unexpected the news is. This is because the market is always building future expectations into prices.

The market estimation of firms and the stock market can be altogether influenced by different factors out of which Monetary Policy announcements are a significant factor that is needed to consider when a speculator or a layman needs to put resources into the Stock Market. Stock prices are among the most intently checked resource prices in the economy and are regularly viewed as being highly sensitive to economic conditions. As the Monetary policy deals with interest rates, open market operations which are tools available to central banks to increase/decrease the money supply in the economy and therefore increasing/decreasing expenditure in the economy. The loose monetary policy period is categorized by an uptrend/boom in stock markets and tight monetary policy is categorized by a downtrend/recession in stock markets in general. The exchange rate is the value of the American dollar versus other currencies. The value of the dollar is both caused and reflected by interest rates, and interest rates have much to do with stock prices. Therefore, exchange rates affect stock prices and can be used to make predictions about the market. Bonds affect the stock market because they both compete for investors' dollars. Bonds are safer than stocks, but they offer a lower return. As a result, when stocks go up in value, bonds go down. When the economy slows, consumers buy less, corporate profits fall, and stock prices decline.

One of the main challenge an investor can face while investing in the stock market is the lack of knowledge about how the factors affect at that time because not all negative news regarding a particular country or company insist to sell shares and not all positive news acts a profitable for a long time. However, if the investor even only identifies the effects or frequency of the effects of major factors that affecting the stock market then he can play

1 Karachi University Business School, University of Karachi, Karachi, Pakistan 
safe and take necessary steps for increasing their investment capital.

Identifying the link between monetary policy and financial resource costs is highly critical to pick up distant better insight in the transmission mechanism of monetary policy since changes in asset prices play a key role in several channels (Christos Ioannidis and Alexandros Kontonikas, 2006).

\subsection{Problem Statement}

Sometimes investor does not recognize the right time to enter or exit in the market which causes them affected by great loss, the investor kept themselves aware of the upcoming events related to the stock market. The investor would invest by taking a long position which means that they hold shares for a very long time only when they feel that upcoming news or upcoming event which is related to the stock market enhance the market otherwise they sell back the shares at a very short time. In recent years, sophisticated institutional traders in the financial markets have increasingly used new sources of information, such as "emotion" signals derived from news articles. Such analytics analysis is made using a computer algorithm and can tell traders within milliseconds whether the article is positive or negative and contains relevant information about the value of a firm. In parallel, increased computerized trade has accelerated the process of accessing such information, and the speed with which it is included in stock prices has increased. Access to such low-latency 'meta-information' - 'news stories' - can provide a competitive advantage to their customers, who are primarily high frequency and algorithmic traders such as hedge funds. However, when false algorithms start trading automatically based on incorrect information, false latency indicators can lead to unexpected results. For example, in April 2013 an incorrect twitter feed about a White House explosion caused a mini flash crash in US markets. Some quickly blamed algorithmic trading for the reaction, while others argued that human traders were mainly responsible. In any case, news reading algorithms may be more likely to misinterpret news than human traders. Thus, understanding the magnitude of the price effects associated with such Meta information is critical for policymakers concerned about financial market stability.

In either case, an important question is whether quick-triggered trading initiated by such low-latency information has an impact on the market that is distinct from the underlying informational content of the news. That is, are there potentially distortionary price effects induced by high-frequency trading based on news analytics? It seems that only the existence of such distortions should justify regulatory intervention.

The important issue is to identify the factors that determine the risks involved in the purchase of a specific asset. The general problem addressed in this research is the factors that influence investors' decision making in the equity market and how equilibrium is established in this market. Therefore, the specific problem under study in this research was the impact of the three main variables or factors i.e. monetary policy, exchange rate, and bond yield while controlling for macro and firm specific-factors, on the equity market. This problem is important to address because the impact of these variables on the economy and economic resource allocation via the equity market seems significant and investors must be aware of the impact of each variable otherwise it will cause a major crash in his/ her investment portfolio.

\subsection{Gap Analysis}

Most studies focused on the real effects of monetary policy on the US stock market. In contrast, (Bohl et al., 2007) analyze the impact of ECB policy on national stock markets in four major European countries. (Martin T. Bohl Pierre L. Siklos David Sondermann, 2008) also found a negative and significant relationship between unexpected ECB decisions and European stock market performance. Further, ECB's monetary policy decisions are well expected from the market, which means that the central bank successfully negotiates its monetary policy. (Syed Mujahid Hussain, 2011) found that the monetary policy decisions generally exert immediate and significant influence on stock index returns and volatilities in both European and US markets. The findings also show that press conferences held by the European Central Bank (ECB) that follow monetary policy decisions on the same day have a clear impact on European index return volatilities. This implies that they convey additional important information to market participants. For a developing country perspective, (Qayyum, Abdul, and Anwar, Saba, 2011) addressed the linkages between the monetary policy and the stock market in Pakistan. The results indicate that any change in the monetary policy stance has a significant impact on the volatility of the stock market.

As discussed above, most of the studies investigated a broader affect change monetary policy variables, very few focused on how fast the impact of monetary policy announcement effect the market based on the daily data. The studies are done to investigate this was either country-specific studies or focused on the EU region. No such study was done on global bases that consist of both developing and developed countries. Hence, they do not provide a comparative analysis for both developed and developing countries with respect to the impact of announcements on the stock market performance. This quantitative study addresses that gap, focusing on the comparative study on the effect of the independent variables Monetary Policy announcement, changes in exchange rates and changes in bond yields on the dependent variable, the stock market return of developed and developing markets. Moreover, we also included exchange rate and bond yields in our analysis, as they too have a profound 
influence on stock prices. (Suriani et. al., 2015; Patoda \& Jain, 2012) as we have not found any study in which analysis is based on the impact of all three components on the stocks market at the same time or multiple countries.

\subsection{Research Objectives}

This paper tries to give detailed empirical evidence on the impact of monetary policy announcements on the stock market Index of 20 nations which are further divided into two categories; Developed and Developing nations. For this, the MP announcement was taken as an independent variable along with changes of exchange rates and bond yields fluctuations serving control purposes. The main aim is to analyze how the development status of the countries plays a role in defining their investment markets in relation to news sentiments regarding the important factors that are a link with their investment markets. The dependent variable was the stock market index. Daily Panel observations of 20 countries for 5 years covering 2014 to 2018 were used for the analysis. The Analysis was done using multiple regression models appropriate for panel data (time series of cross-section) analysis. The developed countries took in this research includes; Switzerland, Japan, South Korea, Canada, Iceland, Spain, Australia, Norway, New Zealand, Singapore whereas the developing countries includes; Pakistan, India, China, Malaysia, Indonesia, Mauritius, South Africa, Philippines, Russia, Czech Republic.

\subsection{Significance}

The purpose of this study is to provide a detailed guideline for the investors as well as brokers/ brokerage firms about the effect of monetary policy along with other factors like the exchange rate and the bond yield on the stock market's performance. As these factors considered to be the most important predictors for stock market performance that's why if the investors understand the linkage between these factors with stock market index then they put their money in the market effectively and must aware that what is the effective time to enter or exit into the market.

The study intended to help individuals and institutional investors make more informed investment decisions and to assist monetary policy authorities in evaluating the impact of monetary policy on the stock market and the same for exchange rates and bond yields and thus taking preemptive actions to prevent stock market crashes.

\subsection{Outline of the Study}

The rest of the paper is organized as follows. The next section (2) discusses the literature review. Section (3) presents the theoretical framework. Section (4) explains the research methodology. Section (5) presents details of descriptive statistics. Section (6) shows the trend analysis. Section (7) lags analysis of monetary policies. Section (8) explains the correlational analysis. Section (9) defines regression analysis. Section (10) provides results and interpretations. Section (11) explains the discussion. Section (12) define conclusion. Section (13) provides a recommendation. Section (14) shows references and in the last section (15) presents the Appendix.

\section{Literature Review: -}

There is a substantial volume of interest in understanding the connections between the stock market index and the variables like monetary policy, exchange rate, and bond yield.

\section{Monetary Policy}

(Christos Ioannidis and Alexandros Kontonikas, 2008), the results of this paper show that changes in monetary policy significantly affect stock returns, and thus support the concept of monetary policy transmission through the stock market. This article examines the impact of monetary policy on stock returns in 13 OECD countries during 1972-2002. First, we show that our findings are robust to various stock exchange alternative measures. Second, our routines have been normalized for display by stock statistics data. (Urs Fischbacher, Thorsten Hens and Stefan Zeisberger, 2013) observe a strong impact of our monetary policy on liquidity in the stock market but only a small impact on bubbles. (Roohollah Zare, M.Azali and M.S.Habibullah, 2013) examined the asymmetric response of stock market volatility to monetary policy over bull and bear market periods in ASEAN5 countries (Malaysia, Indonesia, Singapore, the Philippines and, Thailand) using the well-tested pooled mean group (PMG) technique. Estimating the models using monthly data from 1991:1 to 2011:12, the results show that a contractionary monetary policy (interest rate increases) has a stronger long-run effect on stock market volatility in bear markets than bulls consistent with the prediction of finance constraints models.

\section{Exchange Rates}

(Hajilee, M. \& Al Nasser, O. M., 2014). This article examines the impact of exchange rate uncertainty on the growth of the stock market as one of the most important indicators of financial market development. To do this, they developed a long-term and short-term model (harmonization testing approach) for twelve emerging economies during the period 1980-202010. Estimates from all models suggest that exchange rate fluctuations have a significant impact on the stock market growth in many countries, both short and long. Despite the many similarities in emerging economies, the results obtained in this article show that the effects of exchange rate volatility on the growth of the stock market work through the specific structures and characteristics of each country. 
Similarly, (Sarfaraz Nawaz Khatri, Dr. Muhammad Kashif and Abdul Samad Sheikh, 2017) examined the relationship between exchange rates and stock market prices in Asian economies. This study deals with the comparative analysis of four South Asian countries, namely India, Sri Lanka, Bangladesh, and Pakistan. Economical models such as Johnson's integration test, long-term Granger coefficient test, and vector error correction model (VECM) are applied for short-term analysis. Results showed that there is no long-term relationship except India. Another Study, (Soenen and Henniger, 1988) found a significantly negative relationship between the value of the US dollar and stock prices by using monthly data on stock prices and effective exchange rates for the period 1980-1986. An association was examined by (Bhattacharya and Mukherjee, 2005) between the stock prices and financial sector of currency exchange in India and found no significant integration. Nonlinear Least Square method used by (Ong and Izan, 1999) to find the relationship in between stock prices and exchange rates. They found a very weak association between the US stock market and exchange rates. (Jorion, 1990) determines significant differences across industries by considering the impact of the exchange rate on US multinational firms. The developed countries have experienced less exposure to exchange rate movements as compared to developing or emerging countries. (Kyung-Chun Mun, 2007) examines that higher foreign exchange rate variability mostly increases local stock market volatility but decreases volatility for the US stock market. The extent to which stock market volatility is influenced by foreign exchange variability is greater for local markets than for the US market because exchange rate changes are more strongly correlated with local equity market returns than the US market returns.

\section{Bond Yield}

(John Y. Campbell and Glen B. Taksler, 2003) using panel data for the late 1990s show that idiosyncratic firmlevel volatility can explain as much cross-sectional variation in yields as can credit ratings. This article explores the impact of equity volatility on corporate bond yields. (William F. Maxwell, 1998) examines the strengths and causes of January's impact on the corporate bond market. First, individual investors show seasonal demand for non-investment grade bonds, but they do not show any such seasonal demand for investment-grade bonds. The effect of January is found to be at least two phenomena. The results support the relationship between this disorder and the small strong impact.

\section{Efficient Market Theories}

The theoretical literature on the feasibility of using attractive interest policies as asset bubbles, especially in the stock markets, is unclear. Much of this literature focuses on stochastic asset price bubbles. While the efficient market view claims that stock prices quickly and rationally reflect all public information (so that stock prices follow a stochastic process close to a random walk), the overreaction hypothesis admits to temporary disparities between prices and fundamentals. Prices misbehave because many "noise traders" violate Bayes' Theorem and overreact to new information. Rational "information traders" can do little to counterbalance the behavior of noise traders and they may not want to, anyway (De Long et al. 1989, 1990). As a result, prices overshoot. Eventually, however, they get corrected as actual future events predictably turn out to be either less rosy or more pleasant than originally thought. This price behavior explains the profitability of contrarian strategies: Contrary to market efficiency, prior stock market "Losers" are a much better investment than prior "winners" (De Bondt and Thaler, 1985). In the debate about whether the data may still be consistent with market rationality. Because risk premiums predictably vary through time (Fama and French, 1988) one approach is to study the behavior of so-called smart money. The arguments for market rationality lose force if those traders whom we normally think as sophisticated display the same biases as do naïve subjects in controlled experiments.

\section{Research Methodology}

The perspective of this study was to find out the influence of MP announcements, changes in ER and fluctuations in BY on the stock market index of 20 countries. Quantitative techniques and E-views are used in this research. To analyze the data Panel Least Square (PLS) used in this study.

\subsection{Sampling}

20 different countries took in this research which is further divided into 10 developed and 10 developing countries. Developed countries include Switzerland, Japan, South Korea, Canada, Iceland, Spain, Australia, Norway, New Zealand, Singapore, and developing countries includes Pakistan, India, China, Malaysia, Indonesia, Mauritius, South Africa, Philippines, Russia, Czech Republic. Daily basis data of all the countries regarding the dependent variable. i.e. Stock Market Index (SMI) and independent variables. I.e. monetary policy announcement dates, exchange rates and bond yields data collected from different authentic sources.

\subsubsection{Developed countries}

Developed countries have technology advancement and the economy is highly developed and has higher per capita wage levels. To be considered a developed nation, a nation, for the most part, includes a per capita salary around or over $\$ 12,000$. Moreover, most developed nations have a normal per capita salary of roughly $\$ 38,000$. As of 2010, the list of developed countries included the United States, Canada, Japan, Republic of Korea, Australia, New 
Zealand, Scandinavia, Singapore, Taiwan, Israel, nations of Western Europe, and a few Middle Easterner states. In 2012, the combined populations of these nations accounted for around 1.3 billion individuals. The populations of developed nations are by and large more steady, and it is assessed that they will develop at an unfaltering rate of around $7 \%$ over the following 40 a long time.

\subsubsection{Developing countries}

The second economic category took in this research is developing countries. The most accepted definition of a developing country is one in which industrialization is low and low on the Human Development Index (HDI). A lower HDI score means that citizens of a particular country have a higher life expectancy, lower educational attainment, lower per capita income, and higher fertility rates than other countries. The stock market in Developing countries can be separated assist into decently developed or less developed nations. Modestly developed nations have an inexact per capita wage of between $\$ 1,000$ and $\$ 12,000$.

\subsection{Data Collection}

For this research, data was collected from secondary sources like central bank websites, the World Bank website and the website of investing.com for stock market indexes and others.

\subsection{Variables Specification}

The variables that were used in this paper are a stock market index which is acts as the dependent variable and monetary policy, exchange rate and bond yield act as independent variables.

\subsubsection{Stock Market Index}

The stock market index which acts as a dependent variable in this research paper is calculated by the selected share price (typically a weighted average). A market index is a hypothetical portfolio of investment holdings that represents a segment of the financial market. The calculation of the index value comes from the prices of the underlying holdings. Some indices have values based on market-cap weighting, revenue-weighting, floatweighting, and fundamental-weighting. Weighting is a method of adjusting the individual impact of items in an index. The stock market index can be categorized in several ways. A 'world' or 'global' stock market index - such as MSCI World or the S\&P Global 100 - includes stocks indexes from different and multiple regions. Areas can be defined geographically (such as Europe, Asia) or industrial or income levels (e.g. developed markets, frontier markets). A 'national' index represents the stock market performance of a given country and, reflects investor's sentiment on the state of its economy. The most regular quotes in the market are national indices consisting of stocks of major companies that are listed on one of the country's largest stock exchanges, such as the American S\&P 500, Japanese Nikkei 225, Indian Nifty 50, and British FTSE 100. Many of the indicators are regional, such as the FTSE Advanced Europe Index or the FTSE Advanced Asia Pacific Index. Indicators can be exchange-based, such as the NASDAQ 100 or NYSE 100 100, or exchange groups, such as Euronext 100 or OMX Nordic 40. We took a national stock market index rate of 20 selected countries.

Indexes took in this research paper with respect to the countries are: SMI index for Switzerland, Nikkei 225 index for Japan, KOSPI index for South Korea, S\&P/TSX index for Canada, ICEX Main index for Iceland, IBEX 35 index for Spain, S\&P/ASX 200 for Australia, OSE Benchmark index for Norway, NZX 50 index for New Zealand, STI index for Singapore, KSE 100 index for Pakistan, BSE Sensex index for India, Shanghai 100 index for China, FTSE Malaysia index for Malaysia, JKSE index for Indonesia, Semdex index for Mauritius, FTSE/JSE Top 40 index for South Africa, PSEi Composite index for Philippines, MOEX index for Russia, PX index for Czech Republic.

The basic theory is that when the domestic stock market rises, it gives investors confidence that the country's economy is also rising, leading to increased interest from foreign investors and demand for the domestic currency. Conversely, if the stock market underperforms, confidence falters and foreign investors take their funds back to their currencies.

\subsubsection{Monetary Policy}

Monetary policy is the policy adopted by the monetary authority of a country that controls either the interest rate payable on very short-term borrowing or the money supply, often targeting inflation or the interest rate to ensure price stability and general trust in the currency. Monetary policy endeavors to attain a set of goals that are communicated in terms of macroeconomic factors such as inflation, real output, and business. However, monetary policy actions such as changes within the central bank discount rate have at best a backhanded effect on these factors and significant slacks are included within the policy transmission component. Broader budgetary markets though, for illustration the stock market, government and corporate bond markets, contract markets, foreign trade markets, are speedy to incorporate new information. The Monetary strategy should then assume a significant job in deciding value returns either by adjusting the markdown rate or by impacting market members' desires for future financial movement. Data regarding monetary policy announcement dates were taken from central bank websites of each country. 


\subsubsection{Exchange Rates}

In finance, an exchange rate is a rate at which one currency will be exchanged for another. It is also regarded as the value of one country's currency to another currency. In the retail currency exchange market, different buying and selling rates will be quoted by money dealers. The increase in demand for local currency will force the interest rates to become higher which will ultimately attract foreign investors to invest and gain maximum benefit. The exchange rate of the local currency will appreciate that of foreign currency and shows a negative relationship as also suggested by the Portfolio Balance approach. Daily basis exchange rates with base-dollar of each country were taken from investing.com websites.

\subsubsection{Bond Yields}

Bond yield is the return an investor realizes on a bond. The bond yield can be defined in different ways. Setting the bond yield equal to its coupon rate is the simplest definition. More complex calculations of a bond's yield will account for the time value of money and compounding interest payments. Since bonds and stocks address guarantees on the proportional corporate assets, money related hypothesis suggests that, in a frictionless market, information that is imperative to their sensible worth should contemporaneously impact their benefits. Daily basis data of 10 years bond yield of each country was taken from investing.com websites.

\section{Descriptive Statistics}

In this section, detailed descriptive statistics of both developed and developing countries regarding the stock market index, monetary policy, exchange rate, and bond yield are analyzed.

Table

\begin{tabular}{|c|c|c|c|c|c|c|c|c|c|c|c|c|}
\hline \multirow{3}{*}{ Particulars } & \multicolumn{4}{|c|}{ Model 1} & \multicolumn{4}{|c|}{ Model 2} & \multicolumn{4}{|c|}{ Model 3} \\
\hline & Develop & ped and De & eveloping $\mathrm{C}$ & Countries & & Developed & d Countries & & & Developin & g Countrie & \\
\hline & SMI & MP & ER & BY & SMI & MP & ER & BY & SMI & MP & ER & BY \\
\hline Mean & 10361.2 & 0.01945 & \begin{tabular}{|l|l|}
5 & 731.9431 \\
\end{tabular} & 0.04155 & 7197.448 & 0.01975 & 132.5895 & 0.02221 & \begin{tabular}{|l|}
13585.39 \\
\end{tabular} & 0.01916 & 1342.729 & 0.061262 \\
\hline Median & 5382.79 & 0 & \begin{tabular}{|l|l|}
0 & 15.0876 \\
\end{tabular} & 0.03474 & 5794.82 & 0 & 1.3823 & 0.0215 & 4274.18 & 0 & 35.88 & 0.07062 \\
\hline Maximum & 55065.4 & 1 & 15235 & 0.1624 & 24270.62 & 1 & 1243.13 & 0.07519 & \begin{tabular}{|l|}
55065.37 \\
\end{tabular} & 1 & 15235 & 0.1624 \\
\hline Minimum & 515.23 & 0 & 0.8575 & -0.00628 & 515.23 & 0 & 0.8575 & -0.00628 & 790.09 & 0 & 3.148 & 0.00244 \\
\hline Std. Dev. & 12838.5 & 0.13812 & 2849.988 & 0.0292 & 5792.381 & 0.13914 & 325.9315 & 0.01629 & 16673.96 & 0.13707 & 3943.729 & 0.026092 \\
\hline Skewness & 1.76892 & 6.95867 & 4.166048 & 0.42594 & 0.828878 & 6.90353 & 2.639973 & 0.8555 & 1.084669 & 7.01614 & 2.711631 & -0.40625 \\
\hline Kurtosis & 5.12325 & 49.4231 & 18.57641 & 2.09432 & 2.818866 & 48.6587 & 8.172224 & 3.8879 & 2.52848 & 50.2263 & 8.405002 & 2.516036 \\
\hline Jarqu & 721 & 2444905 & 2.2 & 22 & 05 & 195413 & $|1|$ & 24 & 40.774 & 336 & 4.05 & 0962 \\
\hline Probability & 0.000 & 0.000 & 0.000 & 0.000 & 0.000 & 0.000 & 0.000 & 0.000 & 0.000 & 0.000 & 0.000 & 0.000 \\
\hline & & & & & & & & & & & & \\
\hline Sum & $2.59 \mathrm{E}+08$ & 486 & 18285403 & 1038.04 & 90752622 & 249 & 1671821 & 280.044 & $1.68 \mathrm{E}+08$ & 237 & 16613582 & 757.9981 \\
\hline Sum Sq. Dev. & $4.12 \mathrm{E}+12$ & 476.545 & $2.03 \mathrm{E}+11$ & 21.2927 & $4.23 \mathrm{E}+11$ & 244.083 & $1.34 \mathrm{E}+09$ & 3.34581 & $3.44 \mathrm{E}+12$ & 232.46 & $1.92 \mathrm{E}+11$ & 8.42283 \\
\hline Observations & 24982 & 24982 & 24982 & 24982 & 12609 & 12609 & 12609 & 12609 & 12373 & 12373 & 12373 & 12373 \\
\hline
\end{tabular}

Table 1 provides a complete descriptive statistic which contains three models in which model 1 explain for both developed and developing countries, model 2 explain for only developed countries, and model 3 provides details for only developing countries.

Model 1 is the descriptive data of both developed and developing countries, and by the help of this table we can analyses that the average SMI of all 20 selected developed and developing counters is 10361.2 in the 5 years sample data and the average MP announcements in all countries for 5 years is 0.194, mean ER (with dollar base) is 731.94 whereas the BY has an average value of 0.041. The mid values of the SMI, MP, ER, and BY are 5282.700, 0 (which means that the day with no announcement), 14.77, and 0.034 respectively. The maximum SMI reported in the African stock market in the year 2017, which can be analyses that the South African market performs well than others. The highest ER of 15235.00 noticed in Indonesia in the month of Oct 2018, which is all-time high than other countries took in this research. The highest 10 -year BY i.e. 0.1624 or $16.2 \%$ notice in Russia in the month of Dec 2014. The lowest SMI rate i.e. 515.23 which is reported against Norway in Feb 2016, lowest ER is 0.857 which is noticed in Switzerland in the month of Jan 2015, and lowest BY is -0.006 which is reported in Switzerland in the month of July 2016. The standard deviation of the SMI is higher than its mean which means that most of the indexes are spread out and far from the values of the mean. The standard deviation of MP is less than its mean value which means that the MP announcement average counts are close to its mean. The standard deviation of the ER is far from the mean which means that most of the exchange rates are far from the average rate of ER whereas the standard deviation of BY is 0.029 which is less than the mean which means that most of the values are near to mean.

Model 2 is the descriptive data of developed countries in our sample, and by the help of this table we can analyses that the average SMI of all developed countries is 4197.448 in the 5years sample data and the average MP announcements in all countries for 5 years is 0.019 , mean ER (with dollar base) is 132.58 whereas the BY 
recorded an average rate of 0.02 . The mid values of the SMI, MP, ER, and BY are 5794.82, 1 (which means that the day with the announcement), 1.38, and 0.021 respectively. The maximum SMI reported is 24270.62 which is recorded in the Japanese stock market in the month of Oct 2018, which can be analyses that Japan market performs well than others. The highest exchange rate 1243.13 noticed in South Korea in the month of Feb 2016, which is all-time high than other countries took in this research in the sample size. The highest 10 -year BY rate is 0.075 or $7.5 \%$ notice in Iceland in the month of Jun 2015. The lowest SMI rate is 515.23 which is reported in Norway in Feb 2016, the lowest ER is 0.857 which is noticed in Switzerland in the month of Jan 2015, and the lowest BY is -0.006 which is reported in Switzerland in the month of July 2016. The Standard deviation of the SMI is lower than its mean which means that most of the indexes are near to the values of the mean. The Standard deviation of MP is slightly greater than its mean which means that the MP announcement average counts are somehow close to its mean. The standard deviation of the ER is greater than its mean value which means that most of the exchange rates are far from the average rate of ER whereas the standard deviation of BY is 0.016 which is less than the mean which means that most of the values are near to mean.

Model 3 is the descriptive data of developing countries in our sample, and by the help of this table we can analyses that the average SMI of all developing countries is 13585.39 in the 5years sample data and the average MP announcements in all countries for 5 years is 0.019 , mean ER (with dollar base) is 1342.72 whereas the BY recorded an average rate of 0.06 . The mid values of the SMI, MP, ER, and BY are 4274.18, 0 (which means that the day with no announcement), 35.88, and 0.07 respectively. The maximum SMI reported is 55065.37 which is recorded in the South African stock market in the month of Nov 2017, which can be analyses that the South African market performs well than others. The highest ER 15235.0 noticed in Indonesia in the month of Oct 2018, which is all-time high than other countries took in this research within the sample size. The highest 10-year BY rate is 0.016 or $1.6 \%$ notice in Russia in the month of Dec 2014. The lowest SMI rate is 790.09 which is reported in the Czech Republic in Jun 2016, lowest ER is 3.14 which is noticed in Malaysia in the month of Aug 2014, and lowest BY is 0.002 which is also reported in the Czech Republic in the month of Sept 2016. The standard deviation of the SMI is greater than its mean which means that most of the indexes are far from the values of the mean. The standard deviation of MP is slightly greater than its mean which means that the MP announcement average counts are somehow close to its mean. The standard deviation of the ER is greater than its mean value which means that most of the exchange rates are far from the average rate of ER whereas the standard deviation of BY is 0.02 which is less than the mean which means that most of the values are near to mean.

\section{Trend Analysis}

\section{Table 2: - Time Series/ Trend Graph of SMI, MP, ER, and BY for Developed Countries}

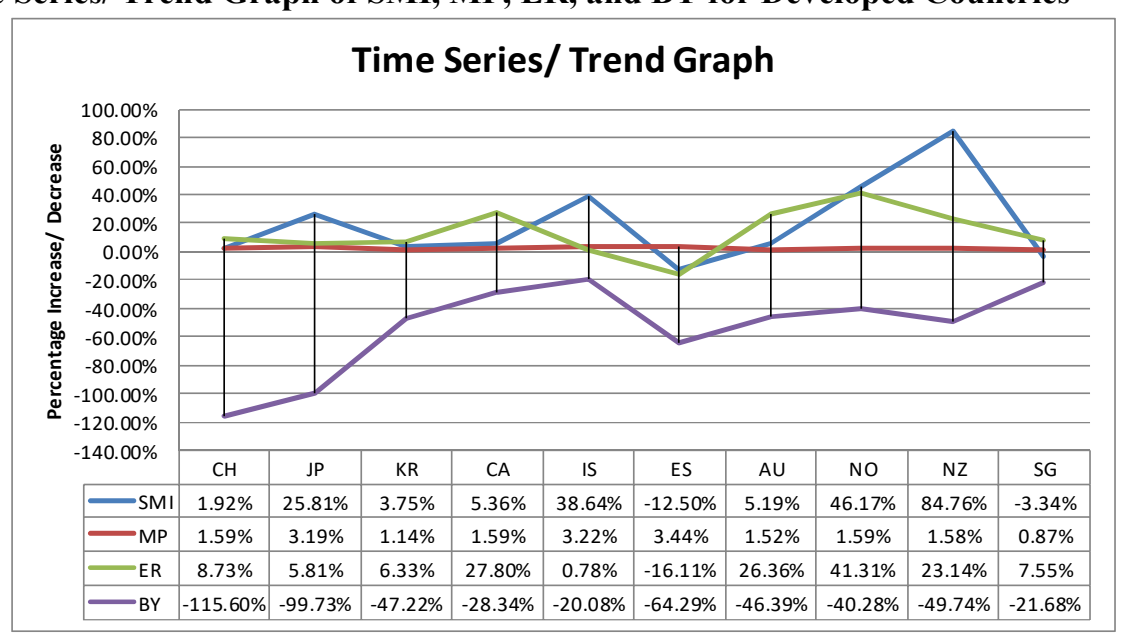

Note: - The percentage of changes calculated by subtracting the first day in the sample size of every variable from their last day and it shows in the vertical axis and country names mentioned in the horizontal axis

The above graph shows the increasing or decreasing trend by the period of 5 years for all variables SMI, MP, $\mathrm{ER}$, and BY of developed countries. It can be analyses that the highest peak of stock market index of New Zealand shows that the index is increased significantly by $84.76 \%$ from the start till the last day of sample size, it can be seen that Spain stock market index decrease the most by $12.50 \%$ in the time period of five years as compared to others. The average announcement of monetary policy for all developed countries is almost the same. During the five years' sample, the exchange rate of New Zealand is increase significantly by $1.59 \%$ which is highest by any other country in our sample data which means that the New Zealand's currency is strengthened by the end of this time period whereas Spain has the decreasing trend in exchange rate also which is evidenced by the decreasing trend shows in this graph by $16.11 \%$. Although all the developed countries have a negative trend in bond yield 
rate in a particular period but the bond yield of Switzerland is decreased by $115.60 \%$ which is worst by any developed countries took in this research.

Table 3: - Time Series/ Trend Graph of SMI, ER, and BY for Developing Countries

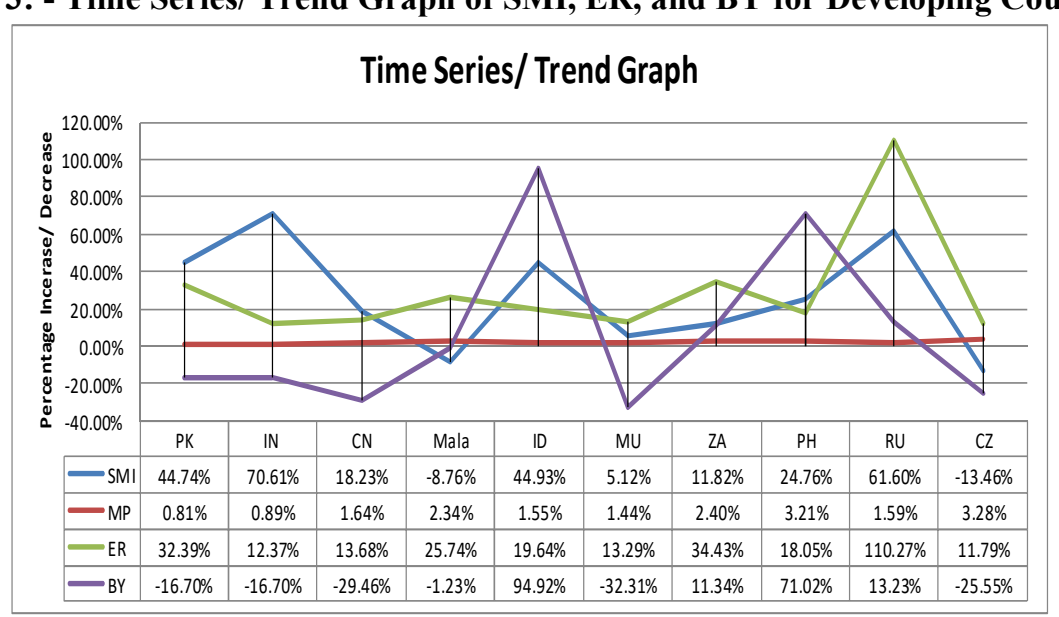

Note: - percentage of changes calculated by subtracting the first day in the sample size of every variable from their last day and it shows in the vertical axis and country names mentioned in the horizontal axis

The above graph shows the increasing or decreasing trend by the period of 5 years for all variables SMI, MP, $\mathrm{ER}$, and BY of developed countries. It can be analyses that the highest peak of stock market index of India shows that the index is increased significantly by $70.61 \%$ from the start till the last day of sample size, it can be seen that Malaysian stock market index decrease the most by $8.76 \%$ in the time period of five years as compared to others. The average announcement of monetary policy for all developed countries is almost the same. During the five years' sample, the exchange rate of Russia is increase significantly by $110.27 \%$ which is highest by any other country in our sample data which means that Russia's currency is strengthened by the end of this time period whereas India has the lowest percentage of increasing trend in exchange rate which is evident by the lowest percentage shows in this graph by $12.73 \%$. Unlike developed countries, some countries have a positive percentage increasing in the 10-year bond yield rate while some have a negative percentage change. The 10-years bond yield rate of Indonesia is increased in five years by $94.92 \%$ while Mauritius has recorded a negative percentage change in the 5 years and has a value of $-32.31 \%$ which is worst by any other developing country took in this research.

Table 4: -

\begin{tabular}{|c|c|c|c|c|c|c|c|c|c|c|c|c|c|}
\hline \multirow{2}{*}{ Category } & \multirow[b]{2}{*}{ Countries } & \multicolumn{3}{|c|}{ Stock Market Index } & \multirow{2}{*}{\begin{tabular}{|c|} 
Monetary Policy \\
Average \\
Announcement \\
of MP
\end{tabular}} & \multicolumn{3}{|c|}{ Exchange Rate } & \multicolumn{3}{|c|}{10 Year Bond Yield } & \multirow[b]{2}{*}{ F-Statistics } & \multirow[b]{2}{*}{$\begin{array}{l}\text { Prob(F- } \\
\text { statistic) }\end{array}$} \\
\hline & & Initial & Ending & $\begin{array}{c}\text { Change in } \\
\%\end{array}$ & & Initial & Ending & $\begin{array}{c}\text { Change in } \\
\%\end{array}$ & Initial BY & $\begin{array}{c}\text { Ending } \\
\text { BY }\end{array}$ & $\begin{array}{c}\text { Change } \\
\text { in } \%\end{array}$ & & \\
\hline Developed & Switzerland & 8270.46 & 8429.3 & $1.92 \%$ & 0.016 & 0.9053 & 0.9843 & $8.73 \%$ & 0.01077 & -0.00168 & $-115.60 \%$ & 23.85 & 0.00 \\
\hline Developed & Japan & 15908.88 & 20014.77 & $25.81 \%$ & 0.032 & 104.22 & 110.28 & $5.81 \%$ & 0.00731 & 0.00002 & $-99.73 \%$ & 98.04 & 0.00 \\
\hline \begin{tabular}{|l|} 
Developed \\
\end{tabular} & South Korea & 1967.19 & 2041.04 & $3.75 \%$ & 0.011 & 1050.55 & 1117.05 & $6.33 \%$ & 0.0367 & 0.01937 & $-47.22 \%$ & 21.3 & 0.00 \\
\hline Developed & Canada & 13594.19 & 14322.86 & $5.36 \%$ & 0.016 & 1.0671 & 1.3638 & $27.80 \%$ & 0.02742 & 0.01965 & $-28.34 \%$ & 141.62 & 0.00 \\
\hline Developed & Iceland & 878.21 & 1217.58 & $38.64 \%$ & 0.032 & 115.5 & 116.4 & $0.78 \%$ & 0.06857 & 0.0548 & $-20.08 \%$ & 74.81 & 0.00 \\
\hline Developed & Spain & 9760.3 & 8539.9 & $-12.50 \%$ & 0.034 & 1.3672 & 1.147 & $-16.11 \%$ & 0.03982 & 0.01422 & $-64.29 \%$ & 54.16 & 0.00 \\
\hline Developed & Australia & 5367.9 & 5646.4 & $5.19 \%$ & 0.015 & 1.1223 & 1.4181 & $26.36 \%$ & 0.04331 & 0.02322 & $-46.39 \%$ & 12.64 & 0.00 \\
\hline Developed & Norway & 546.93 & 799.46 & $46.17 \%$ & 0.016 & 6.1668 & 8.7141 & $41.31 \%$ & 0.02964 & 0.0177 & $-40.28 \%$ & 189.57 & 0.00 \\
\hline \begin{tabular}{|l|} 
Developed \\
\end{tabular} & Newzealand & 4769.04 & 8811.27 & $84.76 \%$ & 0.016 & 1.2087 & 1.4884 & $23.14 \%$ & 0.04761 & 0.02393 & $-49.74 \%$ & 777.89 & 0.00 \\
\hline Developed & Singapore & 3174.65 & 3068.76 & $-3.34 \%$ & 0.009 & 1.2673 & 1.363 & $7.55 \%$ & 0.02606 & 0.02041 & $-21.68 \%$ & 135.79 & 0.00 \\
\hline \begin{tabular}{|l|} 
Developing \\
\end{tabular} & Pakistan & 25608.85 & 37066.67 & $44.74 \%$ & 0.008 & 105.6 & 139.8 & $32.39 \%$ & 0.08848 & 0.0737 & $-16.70 \%$ & 1161.23 & 0.00 \\
\hline \begin{tabular}{|l|} 
Developing \\
\end{tabular} & India & 21140.48 & 36068.33 & $70.61 \%$ & 0.009 & 61.91 & 69.57 & $12.37 \%$ & 0.08848 & 0.0737 & $-16.70 \%$ & 154.19 & 0.00 \\
\hline Developing & China & 2109.39 & 2493.9 & $18.23 \%$ & 0.016 & 6.0507 & 6.8785 & $13.68 \%$ & 0.0464 & 0.03273 & $-29.46 \%$ & 91.82 & 0.00 \\
\hline \begin{tabular}{|l|} 
Developing \\
\end{tabular} & Malaysia & 1852.95 & 1690.58 & $-8.76 \%$ & 0.023 & 3.2865 & 4.1325 & $25.74 \%$ & 0.04146 & 0.04095 & $-1.23 \%$ & 393.59 & 0.00 \\
\hline \begin{tabular}{|l|} 
Developing \\
\end{tabular} & Indonesia & 4274.18 & 6194.5 & $44.93 \%$ & 0.016 & 12170 & 14560 & $19.64 \%$ & 0.04095 & 0.07982 & $94.92 \%$ & 861.61 & 0.00 \\
\hline \begin{tabular}{|l|} 
Developing \\
\end{tabular} & Mauritious & 2110.37 & 2218.52 & $5.12 \%$ & 0.014 & 30.275 & 34.3 & $13.29 \%$ & 0.07982 & 0.05403 & $-32.31 \%$ & 1476.97 & 0.00 \\
\hline Developing & South Africa & 41785.98 & 46726.59 & $11.82 \%$ & 0.024 & 10.684 & 14.3623 & $34.43 \%$ & 0.0798 & 0.08885 & $11.34 \%$ & 10.52 & 0.00 \\
\hline Developing & Philippines & 5984.26 & 7466.02 & $24.76 \%$ & 0.032 & 44.495 & 52.525 & $18.05 \%$ & 0.0412 & 0.07046 & $71.02 \%$ & 92.45 & 0.00 \\
\hline Developing & Russia & 1466.15 & 2369.33 & $61.60 \%$ & 0.016 & 33.21 & 69.8319 & $110.27 \%$ & 0.0771 & 0.0873 & $13.23 \%$ & 1188.75 & 0.00 \\
\hline Developing & Czesch Republic & 264.4 & 228.81 & $-13.46 \%$ & 0.033 & 20.122 & 22.4945 & $11.79 \%$ & 0.02607 & 0.01941 & $-25.55 \%$ & 454.5 & 0.00 \\
\hline
\end{tabular}

Note: - This table presents the data of all twenty (20) selected countries regarding the initial (the first open day of sample size i.e. 01 Jan 2014) and ending value (the last open day of sample size i.e. 31 Dec 2018) of SMI, ER, and BY. Changes in percentage increase or decrease of the stock market index, exchange rates, and 10 years bond yield also mentioned. Average announcements of monetary policies in a sample size for each country. Also F - Statistics against each country also present in the table which is extracted by running the panel least square of each country individually. 
The above table is only focus on the increasing or decreasing trend of stock market index, exchange rate, and bond yield rate of developed and developing countries separately by taking an initial and the last day of the sample size reading and try to analyses the trend and also focus on the jointly effect of these independent variables (MP), (ER), and (BY) on the dependent variable (SMI).

For developed countries, the stock market index of Switzerland slightly increase from Jan 2014 to Dec 2018 as the increasing percentage is $1.92 \%$ also there is an increase in percentage of exchange rate with dollar base from Jan 2014 to Dec 2018 which is increased by 8.73\% whereas the bond yield rate in Switzerland is soundly decreased by $115.60 \%$ in the sample size of five years. In the same sample years, the SMI of Japan is increased by $25.81 \%$ same as the exchange rate is also increased by $5.81 \%$ whereas the bond yield is decreased by $99.73 \%$. The stock market index of South Korea is slightly increased by $3.75 \%$ same as the exchange rate is also increased by $6.33 \%$ whereas the bond yield rate is also decreased by $47.22 \%$ in the sample size of 5 years. The stock market index of Canada is increased by $5.36 \%$, same as the exchange rate of Canada with Dollar base is increased by $27.8 \%$ whereas the bond yield rate is decreased by $28.34 \%$. There is a $38.64 \%$ increase in the stock market index of Iceland and a slight increase of $0.78 \%$ of the exchange rate and a $20.08 \%$ increase in bond yield rate. There is a disastrous trend notice in the five years cycle of stock market index of Spain because the stock market index is decreased by $12.50 \%$ also a declining trend in exchange rate because the exchange rate decrease by $16.11 \%$ same as for the bond yield rate because there is also $64.29 \%$ decrease in bond yield rate of Spain. Spain is the only country in our research that has a decreasing trend in all the variables. The stock market index of Australia is increased by $5.19 \%$ and the exchange rate is increased by $36.6 \%$ whereas the bond yield for Australia in the sample size of five years is decreased by $46.39 \%$. The stock market index of Norway is also increased by $46.17 \%$ with an increased with kits exchange rate by $41.31 \%$ and a decrease in bond yield by 40.28 The stock market index of New Zealand also reflects an increasing trend because the stock market index is increased by $84.76 \%$ which is highest by any country taken in this research, exchange rate is also increased by $23.14 \%$ whereas the bond yield is decreased by $49.74 \%$. The tables show a slight decrease in the stock market index by $-3.34 \%$ and the exchange rate of Singapore is increased by $7.55 \%$. The average announcements of monetary policies for all developed countries are almost the same. The Prob (F-Statistics) values of all developed countries are less than 0.05 which means that we can conclude that all the independent variables have jointly affect the stock market of developed countries.

For developing countries, the stock market index of Pakistan is increased significantly from Jan 2014 to Dec 2018 as the increasing percentage is $44.74 \%$ also there is an increase in percentage of exchange rate with dollar base which is increased by $32.39 \%$ whereas there is a decreasing trend in bond yield rate in Pakistan which shows the decreasing percentage of $16.70 \%$ in the sample size of five years. In the same sample years, the SMI of India is increased significantly by $70.61 \%$ which is most by any developing country in our sample data same as the exchange rate is also increased by $12.37 \%$ whereas the bond yield is decreased by $16.70 \%$. The stock market index of China is increased by $18.23 \%$ the same as the exchange rate is also increased by $13.68 \%$ whereas the bond yield rate is decreased by $29.46 \%$ in the sample size of 5 years. The stock market index of Malaysia is decreased by $8.76 \%$ whereas the exchange rate with Dollar base is increased by $25.74 \%$ and the bond yield rate is slightly decreased by $1.23 \%$. There is a $44.93 \%$ increase in the stock market index of Indonesia and the exchange rate is also increased by $19.64 \% \%$ and $94.92 \%$ increase in bond yield rate. There is a slight increase in the stock market index of Mauritius by $5.12 \%$ and the exchange rate is increased by $13.29 \%$ whereas the bond yield is decreased by $32.31 \%$. The stock market index of South Africa is increased by $11.82 \%$. Same as the exchange rate is increased by the same as the bond yield is also increased by $11.34 \%$. The stock market index of the Philippines is increased by $24.76 \%$ and the exchange rate is increased by $18.05 \%$ whereas the bond yield for the Philippines is increased by $71.02 \%$. The stock market index of Russia is also increased by $61.60 \%$ whereas the exchange rate is also significantly increased by $110.27 \%$ same as the bond yield rate is increased by $13.23 \%$. The stock market index of the Czech Republic shows a decreasing trend of $13.46 \%$ where the exchange rate is increased by $11.79 \%$ and bond yield is decreased by $25.55 \%$. The average announcements of monetary policies for all developed countries are almost the same. The Prob (F-Statistics) values of all developed countries are less than 0.05 which means that we can conclude that all the independent variables have jointly affect the stock market of developed countries. 
6. Lag Analysis of Monetary Policy

Table 5: - Monetary policy analysis on different lags

\begin{tabular}{|l|l|r|r|l|r|r|}
\hline Lags & Category & \multicolumn{1}{c|}{ t-statics } & p - Sig Value & Category & \multicolumn{1}{c|}{ t-statics } & \multicolumn{1}{c|}{ - Sig Value } \\
\hline-4 & Developed & 0.12 & 0.900 & Developing & 0.09 & 0.927 \\
\hline-3 & Developed & -6.01 & 0.000 & Developing & -1.91 & 0.056 \\
\hline-2 & Developed & -0.94 & 0.345 & Developing & -1.49 & 0.136 \\
\hline-1 & Developed & 0.11 & 0.907 & Developing & 0.66 & 0.504 \\
\hline 0 & Developed & -1.57 & 0.116 & Developing & -0.03 & 0.968 \\
\hline 1 & Developed & -5.36 & 0.000 & Developing & -1.75 & 0.079 \\
\hline 2 & Developed & -1.41 & 0.156 & Developing & -1.47 & 0.141 \\
\hline 3 & Developed & -0.36 & 0.714 & Developing & 0.56 & 0.572 \\
\hline 4 & Developed & -1.09 & 0.272 & Developing & 1.37 & 0.170 \\
\hline
\end{tabular}

Note: - This table presents the t-static and p-sig value of all selected developed and developing countries regarding the monetary policy announcements on different lags i.e. $-4,-3,-2,-1,0,1,2,3,4$ by using the Panel Least Square Method.

A test statistic is a standardized value that is calculated from sample data during a hypothesis test. A t-value of 0 indicates that the sample results exactly equal to the null hypothesis. As the difference between the sample data and the null hypothesis increases, the absolute value of the t-value increases. As the table divided is into two categories; developed and developing countries. For developed countries at lag $-4,-2,-1,3$, the t-statistics value is near to 0 which means that the sample results of MP on these lags is exactly equal to the null hypothesis where the t-statistics on other lags i.e. $-3,0,1,2,4$ are far from 0 which means that the evidence is against the null hypothesis. Whereas the p-sig value of developed countries with respect to monetary policy at lag -3 and 1 are less than 0.05 which means that we reject the null hypothesis and assume that there is a significant relationship between MP and SMI at these lags while the sig value at all other lags are greater than 0.05 which means than we accept the null hypothesis and assume that there is an insignificance relationship between MP and SMI at these lags. Below are the graphs which further illustrate the trend of t-statistics and p-sig values of MP of developed countries at different lags:
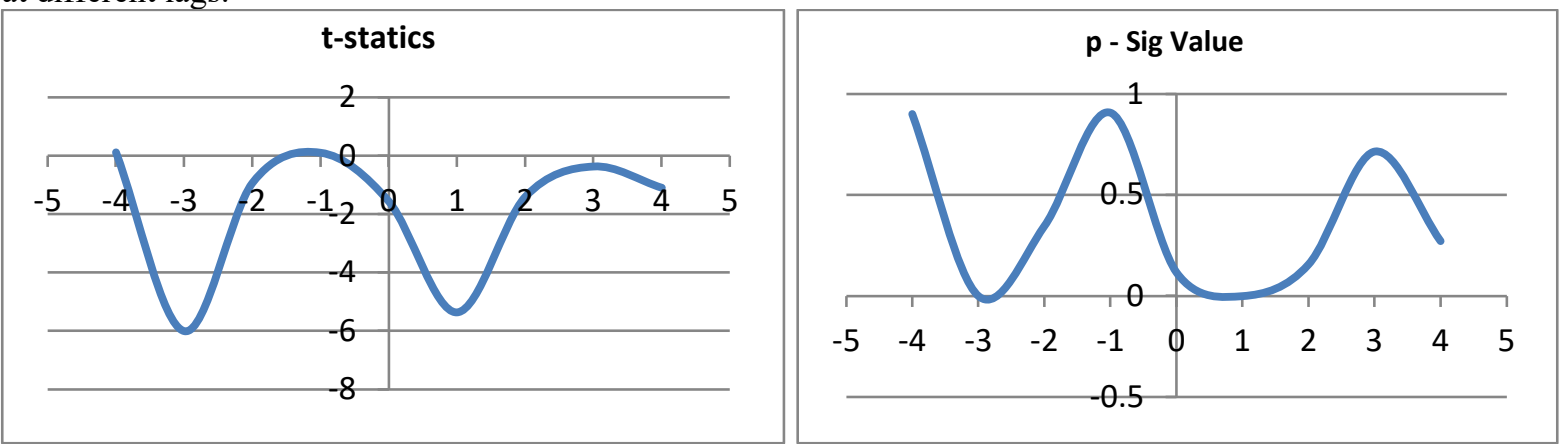

For developing countries, at lag $-4,-1,0,3$ the $t$ statistics are near to 0 which means that the sample results of MP on these lags is exactly equal to the null hypothesis where the t-statistics on other lags i.e. $-3,-2,1,2,4$ are far from 0 which means that the evidence is against the null hypothesis. Whereas the $\mathrm{p}$-sig value of developing countries for MP at all lags is greater than 0.05 which means than we accept the null hypothesis and assume that there is an insignificance relationship between MP and SMI at all lags. Below are the graphs which further illustrate the trend of t-statistics and p-sig values of monetary policy of developed countries at different lags:

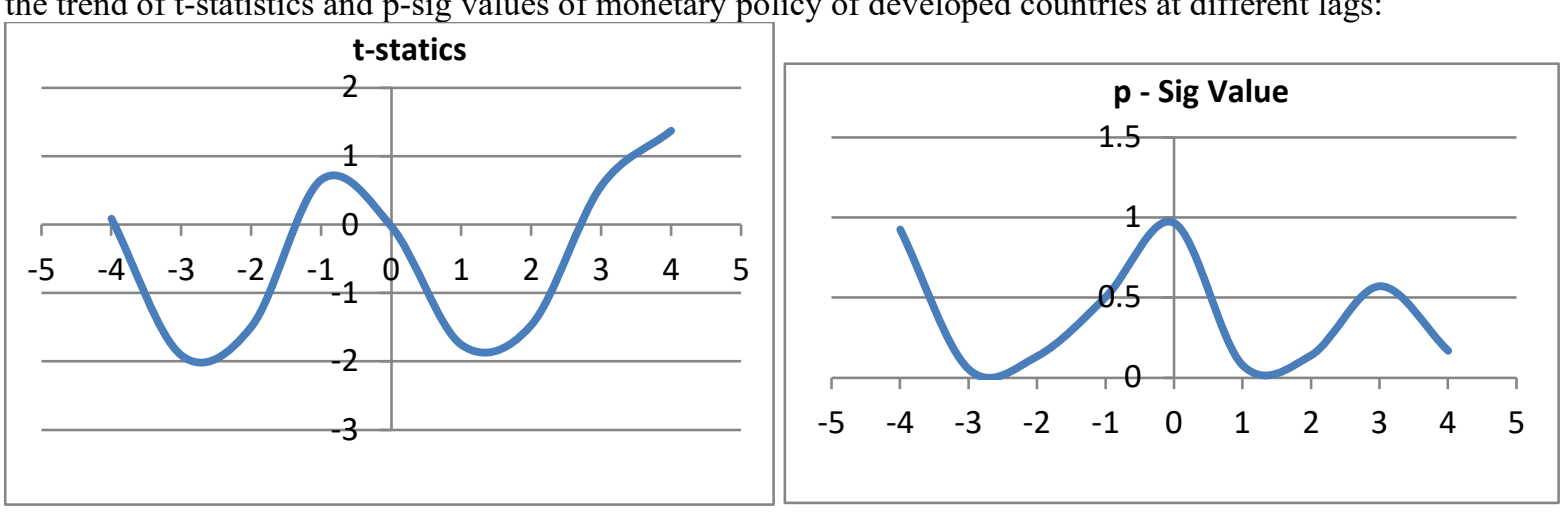




\section{Correlational Analysis}

Table 6: Correlation analysis between Stock Market Index, Monetary Policy, Exchange Rate, and Bond Yield of Both Developed and Developing Countries

\begin{tabular}{|c|c|c|c|c|}
\hline $\begin{array}{l}\text { Correlation } \\
\text { Probability } \\
\end{array}$ & SMI & MP & ER & BY \\
\hline SMI & $\begin{array}{r}1.000000 \\
-----\end{array}$ & & & \\
\hline MP & $\begin{array}{r}-0.007140 \\
0.2591\end{array}$ & $\begin{array}{r}1.000000 \\
----\end{array}$ & & \\
\hline ER & $\begin{array}{r}-0.096796 \\
0.0000\end{array}$ & $\begin{array}{r}-0.007299 \\
0.2486\end{array}$ & $\begin{array}{r}1.000000 \\
----\end{array}$ & \\
\hline BY & $\begin{array}{r}0.355141 \\
0.0000 \\
\end{array}$ & $\begin{array}{r}-0.014848 \\
0.0189 \\
\end{array}$ & $\begin{array}{r}0.266846 \\
0.0000 \\
\end{array}$ & $\begin{array}{r}1.000000 \\
---- \\
\end{array}$ \\
\hline
\end{tabular}

Note: - The above correlation table runs the data of both developed and developing countries and contains correlation and sig value between stock market index, monetary policy, exchange rate, and bond yield.

Table 7: -Correlation analysis between Stock Market Index, Monetary Policy, Exchange Rate, and Bond Yield of Developed Countries

\begin{tabular}{|c|c|c|c|c|}
\hline $\begin{array}{l}\text { Correlation } \\
\text { Probability }\end{array}$ & SMI & MP & ER & BY \\
\hline SMI & 1.000000 & & & \\
\hline MP & $\begin{array}{r}0.021349 \\
0.0165\end{array}$ & $\begin{array}{r}1.000000 \\
----\end{array}$ & & \\
\hline ER & $\begin{array}{r}-0.262073 \\
0.0000\end{array}$ & $\begin{array}{r}-0.013907 \\
0.1184\end{array}$ & $\begin{array}{r}1.000000 \\
----\end{array}$ & \\
\hline BY & $\begin{array}{r}-0.559200 \\
0.0000\end{array}$ & $\begin{array}{r}0.009182 \\
0.3026\end{array}$ & $\begin{array}{r}0.071078 \\
0.0000\end{array}$ & $\begin{array}{r}1.000000 \\
----\end{array}$ \\
\hline
\end{tabular}

Note: - The Above correlation table runs the data of both developed and developing countries and contains correlation and sig value between stock market index, monetary policy, exchange rate, and bond yield. Table 8: -Correlation analysis between Stock Market Index, Monetary Policy, Exchange Rate, and Bond Yield of Developing Countries

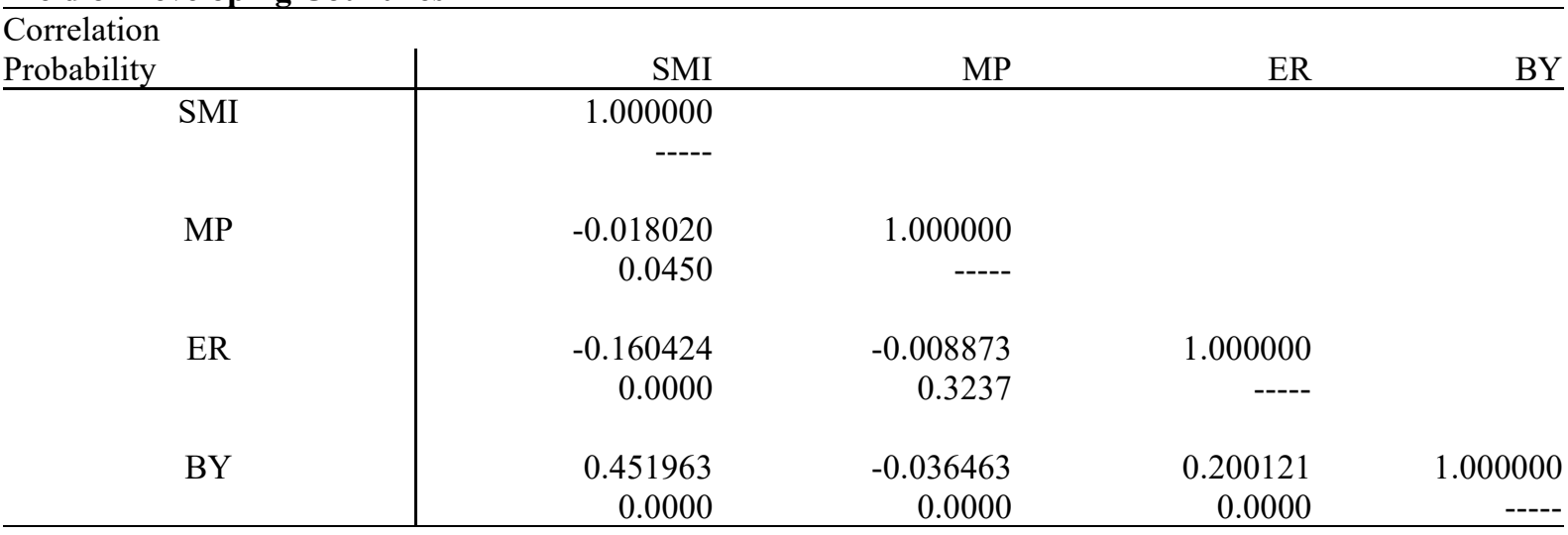

Note: - The above correlation table runs the data of both developed and developing countries and contains correlation and sig value between stock market index, monetary policy, exchange rate, and bond yield. In tables 6 and 8 focusing on overall and developing countries, there is a week and a negative correlation between monetary policy and stock market index. The correlation of the exchange rate with the stock market index and monetary policy is negatively week. There is a positive week correlation between the bond yield and the stock market index. There is also a positive week correlation between the bond yield and the exchange rate. However, for developed countries (Table 7), there was a strong and positive correlation between monetary policy and stock 
market index whereas bond yield and stock market index have a negative and strong correlation.

\section{Regression Analysis}

Further, multiple regression analysis tests are performed in this research. The method used for this test is Panel Least Square method while taking the stock market index (SMI) as dependent variable Y and monetary policy (MP), exchange rates (ER) and bond yield (BY) as an independent variable $\mathrm{X}$. the regression model used for the study is as follows:

9. Results and Interpretations: -

$$
S M I=C+\beta(M P)+\beta(E R)+\beta(B Y)+\epsilon
$$

Table 9: -

\begin{tabular}{|c|c|c|c|c|c|c|c|}
\hline & & Model 1 & Model 2 & Model 3 & Model 4 & Model 5 & Model 6 \\
\hline & & \multicolumn{3}{|c|}{ Developed countries } & \multicolumn{3}{|c|}{ Developing countries } \\
\hline \multicolumn{8}{|c|}{ Dependent Variable: SMI } \\
\hline \multirow{3}{*}{$\mathbf{C}$} & Coefficient & 6724.32 & 6916.09 & 6884.234 & 16443.8 & 16200.55 & 16118.99 \\
\hline & t-Statistic & 69.13602 & 30.87179 & 224.4594 & 82.87819 & 33.19011 & 33.23995 \\
\hline & Prob. & 0.0000 & 0.0000 & 30.67029 & 0.0000 & 0.0000 & 0.0000 \\
\hline \multirow{3}{*}{ MP } & Coefficient & -97.6738 & & 0.0000 & -6.82056 & & \\
\hline & t-Statistic & -1.57354 & & & -0.03971 & & \\
\hline & Prob. & 0.1156 & & & 0.9683 & & \\
\hline \multirow{3}{*}{ MP(-1) } & Coefficient & & 10.14909 & & & 167.2912 & \\
\hline & $\mathrm{t}$-Statistic & & 0.116928 & & & 0.668637 & \\
\hline & Prob. & & 0.9069 & & & 0.5038 & \\
\hline \multirow{3}{*}{ MP(-2) } & Coefficient & & -115.24 & & & -754.557 & \\
\hline & t-Statistic & & -0.945 & & & -1.49331 & \\
\hline & Prob. & & 0.3448 & & & 0.1355 & \\
\hline \multirow{3}{*}{ MP(-3) } & Coefficient & & -1586.52 & & & -1675.72 & \\
\hline & t-Statistic & & -6.01159 & & & -1.9144 & \\
\hline & Prob. & & 0.0000 & & & 0.0557 & \\
\hline \multirow{3}{*}{ MP(-4) } & Coefficient & & 83.48875 & & & 80.26233 & \\
\hline & t-Statistic & & 0.126022 & & & 0.091627 & \\
\hline & Prob. & & 0.8997 & & & 0.927 & \\
\hline \multirow{3}{*}{ MP(1) } & Coefficient & & & -1422.31 & & & -1547.22 \\
\hline & t-Statistic & & & -5.36368 & & & -1.75868 \\
\hline & Prob. & & & 0.0000 & & & 0.0788 \\
\hline \multirow{3}{*}{ МР(2) } & Coefficient & & & -173.237 & & & -747.419 \\
\hline & $\mathrm{t}$-Statistic & & & -1.41952 & & & -1.47147 \\
\hline & Prob. & & & 0.1559 & & & 0.1413 \\
\hline \multirow{3}{*}{ MP(3) } & Coefficient & & & -31.9167 & & & 142.1434 \\
\hline & t-Statistic & & & -0.36606 & & & 0.565088 \\
\hline & Prob. & & & 0.7144 & & & 0.5721 \\
\hline \multirow{3}{*}{ MP(4) } & Coefficient & & & -263.892 & & & 764.9817 \\
\hline & t-Statistic & & & -1.09886 & & & 1.372684 \\
\hline & Prob. & & & 0.272 & & & 0.17 \\
\hline \multirow{3}{*}{ ER } & Coefficient & 4.078779 & 4.158956 & 3.930201 & -0.79207 & -0.72417 & -0.71115 \\
\hline & $\mathrm{t}$-Statistic & 7.217238 & 3.08499 & 2.894233 & -9.33869 & -3.52238 & -3.46662 \\
\hline & Prob. & 0.0000 & 0.0021 & 0.0038 & 0.0000 & 0.0004 & 0.0005 \\
\hline \multirow{3}{*}{ BY } & Coefficient & -2923.56 & -8637.16 & -5900.1 & -29296.1 & -29924.8 & -29277.5 \\
\hline & t-Statistic & -1.06864 & -1.32439 & -0.90351 & -10.943 & -4.47996 & -4.42669 \\
\hline & Prob. & 0.2853 & 0.1855 & 0.3664 & 0.0000 & 0.0000 & 0.0000 \\
\hline \multicolumn{2}{|c|}{ R-squared } & 0.978344 & 0.980323 & 0.980071 & 0.98129 & 0.981841 & 0.9816 \\
\hline \multicolumn{2}{|c|}{ Adjusted R-squared } & 0.975649 & 0.97676 & 0.976484 & 0.979032 & 0.978969 & 0.97869 \\
\hline \multicolumn{2}{|c|}{ F-statistic } & 363.0891 & 275.0851 & 273.2332 & 434.6907 & 341.8743 & 337.3138 \\
\hline \multicolumn{2}{|c|}{ Prob(F-statistic) } & 0.0000 & 0.0000 & 0.0000 & 0.0000 & 0.0000 & 0.0000 \\
\hline \multicolumn{2}{|c|}{ Durbin-Watson stat } & 0.175051 & 1.061901 & 1.072069 & 0.204699 & 1.0165 & 1.011433 \\
\hline \multicolumn{2}{|c|}{ Total panel observations: } & 12608 & 2290 & 2289 & 12373 & 2110 & 2110 \\
\hline \multicolumn{2}{|c|}{ Periods included: } & 1384 & 337 & 335 & 1321 & 274 & 274 \\
\hline
\end{tabular}


The table presents the regressions finding for both developed and developing countries in 6 models; model 1 shows the regression result of developed countries at lag (0), model 2 shows the regression result of developed countries at lags $(-1,-2,-3,-4)$ of monetary policy, model 3 shows the regression result of developed countries at lags $(1,2,3,4)$ of monetary policy. Same as for developing countries model 3, 4, and 5 shows the result for developing countries at lag $(0),(-1,-2,-3,-4)$, and $(1,2,3,4)$ of monetary policy.

For Developed Countries, in all models, the coefficient of MP at lag (-2), (-3), (0), (1), (2), (3), and (4) shows the negative relation with SMI because the values are $(-115.24),(-1586.52),(-97.63),(-1422.34),(-173.23),(-$ $0.36)$, and (-263.89) respectively whereas there is a positive relation at lag $(-1)$, and (-4) because the values are (10.14) and (83.48) respectively. It seems that at the day when MP announces the SMI will suffer because the coefficient of MP at lag (0) shows a negative value of -97.63 but the sig value at lag (0) shows that there is an insignificant relationship between MP at lag (0) and SMI, it is maybe because normally it can be seen that the MP announced in the time of mid-day, till that time the stock market of certain country is near to closing hence the effect of MP is not much reflected in the day of its announcement. With reference to BY, the coefficient of bond yield in all models shows a negative relation with SMI because the values are -2933.56, -8637.16, and -5900.1 respectively but the bond yield at the same time have an insignificance relationship with SMI of developed countries because the sig value is greater than 0.05 at all lags of MP. So, there is no impact of bond yield on the stock market index of developed countries. However, ER has a positive relationship with the stock market index for developed countries at all lags of MP because the coefficients of ER are 4.07, 4.15, and 3.93 for models 1, 2, and 3. As the sig value of ER is less than 0.05 so therefore we can say that there is a significant relationship between the ER and the SMI of developed countries. It has been seen normally that when money is cheap, the economy will expand because more businesses will build capital stock, expand their production and continue to borrow money. For the short term, cheap money suggests the stock market will show price rises across the board. Cheap money means that the exchange rate is starts rising. So as per our analysis, there is also an increasing trend and concluded that when 1 unit change in ER, the SMI of developed countries will rise by approx. 4 units because of the coefficient of the ER at all models of developed countries is near to 4.

For Developing Countries, in all models, the coefficient of MP at lags (-2), (-3), (0), (1), and (2) shows the negative relation because the values are (-754.55), (-1675.52), (-6.82), (-1547.22), and (-747.41) respectively whereas there is a positive coefficient at lag (-1), (-4), (3), and (4) i.e. (167.29), (80.26), (142.14), and (764.98) respectively. The sig value at all lags is greater than 0.05 which means that there is an insignificance relationship between MP at all lags and SMI of developing countries. Therefore, in comparison, we can say that the developed countries seem to react more significantly to MP announcements as compared to developing countries. As the economy of developed countries is mostly documented as compared to developing countries however the changes in the interest in the monetary policy announcement affect the performances of their financial markets of developed countries most whereas the developing countries do not have a significant effect due to announcement of monetary policy because mostly in developing countries the economy is not fully documented which is considered to be the main reason. Also, the financial market in developing countries is highly under-developed. Due to the unorganized nature of the money market and lack of its integration with the central bank, the traditional methods of credit control like bank rate policy, open market operations and variations in the reserve ratio etc. have got a limited effect. In the same manner, the study Ludmilla Buteau (2011), runs the test for MP effectiveness of less developed economies using a panel of underdeveloped and developing countries. The results show that in all of these countries, show that MP through interest rate isn't as efficient as it should be. The exchange rate channel has a more significant impact when trying to impact growth particularly in countries with very low levels of financial development. However, our research shows the same result for developing countries or less developed countries. With regards to BY, as the relationship is negative for all models but insignificant for developed countries, whereas significant for developing countries. While there are exceptions, the equity markets have normally moved negatively with bond yields. That means as bond yields go down, the equity markets tend to outperform by a bigger margin and as bond yields go up equity markets tend to falter. This relationship may not exactly held in the very short run. But if you consider it over a period of 5-10 years, this relationship will be clearly visible. As our analysis also explains that when the BY increases in developing countries the SMI starts decreasing because the reason behind this is that the bond yields, in a way, represent the opportunity cost of investing in equities. For example, if the 10 -year bond is yielding $7 \%$ per annum then the equity markets will be attractive only if it can earn well above $7 \%$. In fact, equity being risky there will have to be a risk premium, first of all, to be even comparable. Let us assume that the risk premium on equities is $5 \%$. Therefore, that $12 \%$ will act as the opportunity cost for equity. Below $12 \%$, it does not make sense for the investor to take the risk of investing in equities as even the additional risk is not being compensated. The question of wealth creation only begins after that. As bond yields go up the opportunity cost of investing in equities goes up and therefore equities become less attractive. That is the main reason that explains the negative relationship between bond yields and equity markets, as in our results the coefficient of bond yield in all models shows a negative value of $-2933.56,-8637.16$, and -5900.1 respectively but the bond yield at the same time have a significant relationship with SMI of developing countries because the sig 
value is less than 0.05 at all lags of monetary policy. So, therefore we can say that there is a significant impact of bond yield on the stock market index of developing countries. However, ER has a negative relationship with the SMI for developing countries at all lags of monetary policy because the coefficients of ER are $-0.79,-0.72$, and 0.71. As the sig value of ER is less than 0.05 so therefore we can say that there is a significant relationship between the ER and SMI of developing countries.

As discussed above, the ER behaved positively for a developed countries and negatively for developing. Furthermore, it remained significant throughout all models, seems to depict a very strong effect on stock returns

The value of $\mathrm{R}$ squared in all the models was about $98 \%$ which means that $98 \%$ of the effect is due to the independent factors and the other $2 \%$ variance is may be due to other factors.

Model 2, and 5 show a positive relation of MP at Lag $(-1)$ and at $(-4)$ and a negative relation with SMI at lag $(-2)$ and $(-3)$ which means that Second $\left(2^{\text {nd }}\right)$ and Third $\left(3^{\text {rd }}\right)$ day before the announcement of monetary policy the SMI will decrease. Mentioned above the overall conditions from model 2 and model 5 but only at lag $(-3)$ of model 2 has a significant relationship with SMI which means that 3 days before the announcement of monetary policy, the stock market of developed is suffered. It is observing that when the monetary policy announced there are some changes occurs in the economic system and due to expected humor regarding the results of monetary policy, the investors' confidence shake and they take safety steps or sometimes put their money back just to re-investlwhen the economy is stable and be on track again. However, it affects the stock market index for a short time after some moments the stock market will start enhancing when the government take the necessary step which is predefined in respect to the current situations of the economy, as we have developed and developing countries both and due to the data runs on different lags therefore the significance of data owns much importance to analyses the real effect. In lag $(-1,-2,-3,-4)$, the sig value of MP in Lag (-3) is less than 0.05 which means that we can conclude that there is a significant relationship between MP and SMI of developed countries before the 3 days of announcing it. Whereas the sig value of before one day, two days and fourth day that is $(-1,-2,-4)$ are greater than 0.05 which means that there is no insignificance relationship in between monetary policy announcement and stock market index of developed countries at these $(-1,-2,-4)$ lags. Model 2 contains the regression analysis of developed countries. As the sig value at lag (-3) in model 1 is less than 0.05 which means that there is a significant relationship between SMI and MP at lag (-3) of developed countries which can be further assumes that the SMI of developed countries seems decreasing trend (due to negative value of coefficients at lag (-3)) and index decreased by 1586.52 before the 3 day of announcement of policy, this is maybe because in the pre-announcement days of MP there is a humor floating in the market regarding the expected uncertainty due to fluctuations in the interest rate and discounts rate which is announced in MP. However, concerning developed countries as it can be seen that the SMI is decreased than it may be a cause of floating uncertainty regarding the fluctuations in interest rates because interest rates define most of the economic indicators. As the model 5 belongs to developing countries and due to their sig value is greater than 0.05 at all lags, so there is an insignificance relationship between MP and SMI at the lags mentioned in model 5 therefore we can say that there is no any impact of monetary policy announcements on the stock market index of developing countries. As our null hypothesis is" there is an insignificance relationship between monetary policy and stock market index". So here in model 2 , the sig value at lag (-3) is less than 0.05 which force reject our null hypothesis which means that the SMI of developed countries shows the decreasing trend at 3 days before the announcement. Whereas the sig values at all the other lags in model 2 and model 5 are greater than 0.05 which force us to accept our null hypothesis which means that there an insignificant relationship hence there is no impact of MP announcement on the SMI at all these lags.

In Model 3, and 6, there is a negative relation of MP at Lag (1), Lag (2) with SMI which means that in these two days after the announcement of monetary policy the SMI will decrease. However, for Lag (3) and Lag (4), developed countries' coefficient stayed negative as in previous cases of models 1 and 2, but developing countries have a positive impact. Model 3 contains the regression analysis of developed countries. As the sig value at lag (1) in model 3 is less than 0.05 which means that there is a significant relationship between SMI and MP at lag (1) of developed countries which can be further assumed that the SMI of developed countries seems to decrease (due to negative coefficient at lag (1)) and decreased by 1422.31 after the 1 day of announcement of policy. However, at all other lags the sig values are greater than 0.05 which means that there is an insignificance relationship with the stock market index so there is no impact of monetary policy at all other lags on the stock market index of developed countries. As the model 6 belongs to developing countries and due to their sig value at all lags present in this model is greater than 0.05 , there is an insignificance relationship between MP and SMI at the lags mentioned in model 6 therefore we can say that there is no any impact of monetary policy on the stock market index of developing countries. In lag $(1,2,3,4)$, the sig value of Monetary Policy in Lag (1) only is less than 0.05 which means that there is a significant relationship between MP and SMI of developed countries after $1^{\text {st }}$ day of announcing it. Developed countries have a higher significant effect as compared to developing countries. Whereas the sig value at Lag (2), Lag (3), and Lag (4) are greater than 0.1 which means that there is no significant relationship in between two, three and four days after the MP announcement and SMI of developed countries at these lags. As we mentioned already that the MP announced in the mid-day time at the time when the stock market 
starts turning off so the effect of monetary policy is logically being reflected on the next day of its announcement. Mostly new policies make some changes in the economic system however it took some moments to economic system to be back on track therefore generally the first day after the announcement of monetary policy the stock market reflects the decreasing trend as we analyze in our paper. As our null hypothesis is" there is an insignificant relationship between monetary policy and the stock market index". So here in model 3, only the sig value at lag (1) is less than 0.05 which force us to conclude that there is a significance relationship between SMI and MP at lag (1) which means that the stock market index of developed countries shows the decreasing trend at the day after the announcement of policy. Whereas in model 6 , all sig values are greater than 0.05 which means that there is no impact of MP on the SMI of developing countries.

\section{Discussions}

Our analysis suggested that the stock market of developed countries performs well as compared to developing countries in the sample period of 5 years, the exchange rate of developing countries is increased significantly in the 5 years as compared to developed countries also 10 years bond yield of developing is better than developed countries. It has been seen that the monetary policy has significance relation monetary policy at lag -3 and 1 for developed countries; however, the monetary policy is not the significant predictor for the stock market index of developing countries, there is almost a week and negative correlation among all the variables observe by the correlation test.

In this manner, the study (Richard D.F Harris, 1997) found that the stock market effect may be weaker than they found. For the less developed sample, the stock market effect, as with the full sample, is at best very weak. For the developed countries, however, stock market activity does have some explanatory power. Our findings are in much more in detail, the regression found that the for developed countries monetary policy at lag ( -3$)$ and Lag (1) and exchange rate is a predictor to make significant impact on the performance of stock market index where bond yield does not make a sense to affect the stock market index. However, for developed countries, it can be seen that the result is against the null hypothesis for both exchange rates and 10 years bond yield rate which means that the exchange rate bond yield affects the stock market performance while the monetary policy does not make any impact on the stock market index.

\section{Conclusion}

Impact of monetary policy announcement on the stock market performance of developed and developing countries along with other variables like ER and BY, itself very interesting concern for the investors and stock related bodies. Previous researches provide different arguments on the impact on the stock market index by different factors. This paper fills the gap which is already highlighted in the gap analysis section i.e. the comparative study on the performance of the stock market index of both developed and developing countries. However, this paper tried to analyses the impact of monetary policy, exchange rates and bond yields on both developed and developing countries' stock market performance. Daily basis data used in this research of all the dependent and independent variables whereas monetary policy announcement dates of countries are gathered which is also acts as an independent variable and run multiple tests and analyses the results like trend analysis provide the performance of stock market index, frequency of exchange rate and bond yield rate fluctuations of all countries. The effects of monetary policy on SMI are analyses on different lags just to check the availability of effect in the near dates of announcement days also. Correlation analysis gives the overall picture of the relationships among variables. Furthermore, the regression model examines the effect of the announcement of monetary policy, changes in exchange rates and changes in bond yields on stock market performance accordingly. As the Monetary policy data is run on three different lags i.e. (0), $(-1,-2,-3,-4),(1,2,3,4)$. So this research paper concludes that exchange rate and monetary policy [at lag (-3), and (1) only] are a predictors of developed countries' stock market index and there is a positive relation between stock market index and exchange rate which means that on average when stock price increase, it increases stock market index and negative relation between stock market and monetary policy [at lag (-3)]. However, there is no relation between the bond yield and stock market Index, which can be further concluded that bond yield is not the predictor of the stock market index in developed countries. However, for developing countries, it has been concluded that monetary policy is not the predictor of the stock market index at all, while the exchange rate and bond yield has a significant relationship with the stock market index and has a negative impact of both variables on the stock market index.

\section{Recommendation}

From the foregoing, this study recommends that the central bank of developed countries must ensure effective implementation of monetary policy to maintain favorable interest rates and exchange rates because these elements reflect the soundly effect on stock market performance in developed countries. The investors who belongs to developed countries and/ or wants to invest in the stock/ equity market of developed countries must keep their eyes on exchanges rates fluctuations and monetary policy announcements and must estimate the pre and post 
announcement effect of monetary policy if the interest rates go up or down or remains constant because both of these elements significantly predict the stock market. Same as for the investors of developing countries, they should also keep their eyes on these elements except monetary policy because the exchange rate and, bond yield have a significant impact on stock market performance. The investor in the stock no matter he/ she belongs to any category of country. He/ She must be clever and must be aware that when the change in these elements (monetary policy, exchange rates, and bond yields) affects their investment so they can take some important steps before they bare losses.

\section{References}

Ioannidis, C., \& Kontonikas, A. (2006). Monetary policy and the stock market: some international evidence. UK: University of Bath and University of Glasgow.

Bohl, M. T., Siklos, P. L., \& Sondermann, D. (2007). Shocking markets: European stock markets and the ECB's monetary policy surprises. Available at SSRN 1091133

Bohl, M. T., Siklos, P. L., \& Sondermann, D. (2008). European stock markets and the ECB's monetary policy surprises. International Finance, 11(2), 117-130.

Hussain, S. M. (2011). Simultaneous monetary policy announcements and international stock markets response: An intraday analysis. Journal of Banking \& Finance, 35(3), 752-764.

Qayyum, A., \& Anwar, S. (2011). Impact of monetary policy on the volatility of stock market in Pakistan.

Suriani, S., Kumar, M. D., Jamil, F., \& Muneer, S. (2015). Impact of exchange rate on stock market. International Journal of Economics and Financial Issues, 5(1S), 385-388.

Patoda, R., \& Jain, K. (2012). Assimilation between bond market and stock market. Global Journal of Management and Business Research, 12(20).

Ioannidis, C., \& Kontonikas, A. (2008). The impact of monetary policy on stock prices. Journal of policy modeling, 30(1), 33-53.

Fischbacher, U., Hens, T., \& Zeisberger, S. (2013). The impact of monetary policy on stock market bubbles and trading behavior: Evidence from the lab. Journal of Economic Dynamics and Control, 37(10), 2104-2122.

Zare, R., Azali, M., \& Habibullah, M. S. (2013). Monetary policy and stock market volatility in the ASEAN5: Asymmetries over Bull and Bear markets. Procedia Economics and Finance, 7, 18-27.

Hajilee, M., \& Al Nasser, O. M. (2014). Exchange rate volatility and stock market development in emerging economies. Journal of Post Keynesian Economics, 37(1), 163-180.

Khatri, S. N., Kashif, M., \& Shaikh, A. S. (2017). THE EXCHANGE RATE AS SIGNIFICANT PREDICTOR OF MOVEMENT IN STOCK MARKET INDICES IN SOUTH ASIAN COUNTRIES: AN ECONOMETRIC ANALYSIS. Journal of Business Strategies, 11(2), 107-123.

Soenen, L. A., \& Hennigar, E. S. (1988). An analysis of exchange-rates and stock-prices-the united-states experience between 1980 and 1986. Akron Business and Economic Review, 19(4), 7-16.

Bhattacharya, B., \& Mukherjee, J. (2005). An analysis of stock market efficiency in the light of capital inflows and exchange rate movements: The Indian context. ICRA Bulletin Money and Finance.

Ong, L. L., \& Izan, H. Y. (1999). Stocks and currencies: Are they related? Applied Financial Economics, 9(5), 523-532.

Jorion, P. (1990). The exchange-rate exposure of US multinationals. Journal of business, 331-345.

Mun, K. C. (2007). Volatility and correlation in international stock markets and the role of exchange rate fluctuations. Journal of International Financial Markets, Institutions and Money, 17(1), 25-41.

Campbell, J. Y., \& Taksler, G. B. (2003). Equity volatility and corporate bond yields. The Journal of finance, $58(6), 2321-2350$.

Maxwell, W. F. (1998). The January effect in the corporate bond market: A systematic examination. Financial Management, 18-30.

De Long, J. B., Shleifer, A., Summers, L. H., \& Waldmann, R. J. (1990). Noise trader risk in financial markets. Journal of political Economy, 98(4), 703-738.

De Bondt, W. F., \& Thaler, R. (1985). Does the stock market overreact? The Journal of finance, 40(3), 793-805.

Fama, E. F., \& French, K. R. (1988). Permanent and temporary components of stock prices. Journal of political Economy, 96(2), 246-273.

Buteau, L. (2011). Monetary policy in less developed economies: a cross-country analysis.

Harris, R. D. (1997). Stock markets and development: A re-assessment. European Economic Review, 41(1), 139146. 


\section{Appendix}

\begin{tabular}{|l|l|}
\hline \multicolumn{2}{|c|}{ List of Abbreviations } \\
\hline SMI & Stock Market Index \\
\hline MP & Monetary Policy \\
\hline ER & Exchange Rate \\
\hline BY & Bond Yield \\
\hline CH & Switzerland \\
\hline JP & Japan \\
\hline KR & Korea \\
\hline CA & Canada \\
\hline IS & Iceland \\
\hline ES & Spain \\
\hline AU & Australia \\
\hline NO & Norway \\
\hline NZ & New Zealand \\
\hline SG & Singapore \\
\hline PK & Pakistan \\
\hline IN & India \\
\hline CN & China \\
\hline Mala & Malaysia \\
\hline ID & Indonesia \\
\hline MU & Mauritius \\
\hline ZA & South Africa \\
\hline PH & Philippines \\
\hline CZ & Czech Republic \\
\hline
\end{tabular}

